\section{Suez Rift}

SrR,-McKenzie et al. ${ }^{1}$ have recently claimed that an extension has taken place across the Gulf of Suez rift, due to continental separation, of 60 to $90 \mathrm{~km}$. As Freund ${ }^{2}$ has rightly pointed out, this is an impossible figure because the average width of the rift in this region does not exceed $60 \mathrm{~km}$; therefore he would estimate a maxi mum extension of 25 to $30 \mathrm{~km}$. But even this amount is widely in excess of the evidence established by field investigation.

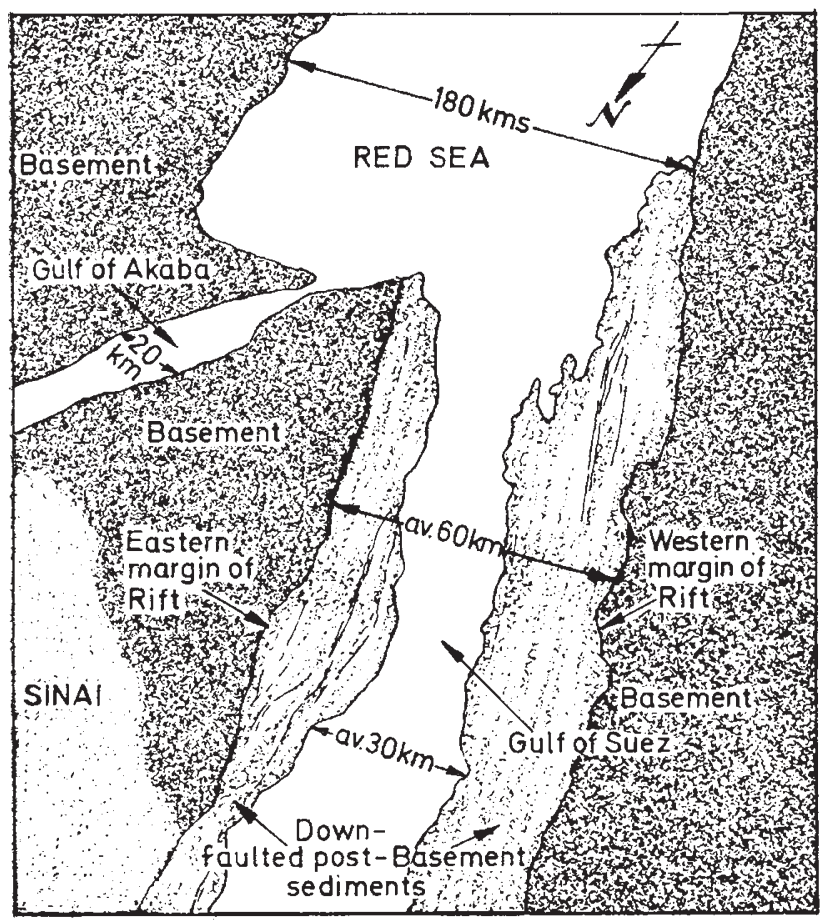

The accompanying figure is a sketch of part of a spacecraft photograph which delineates the rift boundaries with great clarity. The camcra was pointing towards the south-east. The photograph illustrates, in the Red Sea region, that the waters occupy the total width of the rift valley, about $180 \mathrm{~km}$, up to the marginal faults on either side. The same is true of the Gulf of Akaba, though the latter rift is only $20 \mathrm{~km}$ wide. However, the Gulf of Suez occupies only the central part of the graben which Hume $^{3}$ described as the Clysmic rift. 'I'he land-strip on either side of the Gulf of Suez, within the Clysmic rift, consists of sediments of Palaeozoic, Mesozoic and Tertiary age, in which the structural details are admirably displayed. These sediments have been subjected to intensive block-faulting movements.

I have recorded the details of this faulting as they occur within the eastern (Sinai) land strip. It is very unlikely that extension across this region, due to the downthrowing movements of the highly dipping normal faults, can exceed 2 to $3 \mathrm{~km}$. The downthrows of the faults within the western land strip could also account for an extension of a further 2 to $3 \mathrm{~km}$. Similarly, the extension across the central part of the Clysmic rift, that underlying the Gulf of Suez, is probably of the same order. Moreover, the evidence, on land, for lateral extension within the Clysmic rift, due to intrusion of dykes, is almost negligible - a few tens of metres. Nor do geophysical data provide evidence for any significant dyke injection beneath the Gulf of Suez, as is known to occur in the central and southern regions of the Red Sea. In any case, igneous activity in the Clysmic rift ceased at the end of Oligocene times.
The geological evidence therefore would support an extension across the Clysmic rift up to perhaps $9 \mathrm{~km}$, but this is quite incompatible with the proposition put forward by McKenzie et al., or indeed by Freund. This extension, which reaches a maximum towards the southern end of the Clysmic rift, must gradually become reduced to zero in the north where, in the latitude of the Mediterranean, the Clysmic rift faults die out. Finally, it is a moot point whether this extension represents crustal separation or whether it may not have been a simple movement of foundering in order to take up the stretch imposed by the arching of the crust across the region or during the initiation of Clysmic rift movements.

\section{Yours faithfully,}

\section{A. Robson}

Department of Zoology,

University of Newcastle upon Tyne.

'McKenzie, P. D., Davies, D., and Molnar, P., Nature, 226, 243 (1970).

2 Freund, R., Nature, 228, 453 (1970).

${ }^{8}$ Hume, W. F., Quart. J. Geol. Soc. Lond., 77 (1921).

\section{Filter Efficiency}

SrR,-We feel it our duty to draw to your attention and to contradict what we consider to be a dangerous state. ment in the leader on the Pirbright outbreak of foot-andmouth disease (Nature, 228, 403; 1970) in which the writer states unequivocally, "but it is well known that no biological filter can be more than 99.9 per cent efficient....".

This could not be further from the truth. To cite the encyclopaedic literature on filter physies and testing is not possible in a short letter, and it must suffice to point out that without filters of 100 per cent efficiency the rearing of germ-free animals and the success of many large scale tissue culture and fermentation processes would be difficult, if not impossible, and furthermore, many other techniques, both microbiological and even surgical, would be extremely hazardous.

Filters providing a degrce of sterility which for practical purposes can be regarded as total are in everyday use, are simple to construct, and readily available commercially.

Yours faithfully,

Superintendent,

J. S. PATERSON

Allington Farm,

Porton.

Physics Division,

CDE, Porton.

Head, Hygiene Section, MRE, Porton.

Head, Technical Services,

MRE, Porton

Sir,-We would agree that your editorial statement "that no biological filter can be more than 99.9 per cent efficient" might be misinterpreted.

The problem at Pirbright is to filter large quantities of air from the laboratories and animal accommodation. The filters used are commercially available and their efficiency is quoted as 99.99 per cent on the sodium flame test procedure. Tests on the filter material used ${ }^{1}$ indicated that for filtration of aerosols of the virus of footand-mouth disease the efficiency was 99.99 per cent or greater. The filters are arranged so that outgoing air must pass through two in series. 